William R. Emmons is a economist and Frank A. Schmid is a senior economist at the Federal Reserve Bank of St. Louis. Judith Hazen, Robert Webb, and Marcela Williams provided research assistance.

\section{The Asian Crisis and the Exposure of Large U.S. Firms}

\author{
William R. Emmons \\ and Frank A. Schmid
}

TT he financial and economic crises that ravaged Thailand, Indonesia, South Korea, Malaysia, and other Asian countries during 1997 and 1998 triggered one of the most abrupt and severe economic slowdowns seen anywhere in the world during recent decades. Financial-market volatility increased around the globe soon after the Thai devaluation of July 1997, reaching its high point in October 1998. Many countries were not hit directly by this financial crisis; nonetheless, they felt significant repercussions. Worldwide economic growth slowed, risk premiums in debt markets increased, stock markets became more volatile, and confidence indicators slumped in many countries (see Economic Report of the President, 1999, pp. 227-51, for an extensive discussion of the Asian crisis).

We examine how the Asian financial crisis affected the sensitivity of large U.S. firms to U.S. stock-market risk - that is, whether the economic situation in Asia is related to changes in firms' "betas." Following corporate finance theory, we define stockmarket exposure as the extent to which a firm's stock returns are correlated with overall market returns. Exposure is summarized by the firm's estimated beta, which, according to the Capital Asset Pricing Model (CAPM), is simply the coefficient estimated in a regression of the firm's excess returns-i.e, dividends plus price change less the risk-free return-on market excess returns over some specified period. ${ }^{1}$ If a firm's beta rises, investors demand higher excess returns for holding its stock. This raises the firm's cost of equity capital. Thus, firms that saw their betas rise as a result of the crisis would face higher equity financing costs.

If the Asian crisis mattered at all for U.S. firms' stock-market risk, we would expect the largest effects at firms with the highest relative sales expo- sure to Asia. Similarly, we would speculate that the betas of firms with relatively low sales exposure to the Asian region would remain unchanged or decrease Betas are measures of a firm's return sensitivity relative to the market, so some betas must go down if others go up. In addition, we would expect firm leverage (debt as a percentage of assets) to amplify the effects of the Asian crisis on firms' CAPM betas. This is because contractually fixed payments owed to debtholders do not change even if underlying cash flows are reduced. This is in contrast to the situation of equity investors, who hold the residual cash flow rights. The more highly leveraged a firm is, the larger the income variability to which the equity holders are exposed, everything else being equal. This income variability is related directly to the amount of total assets the firm controls or its sales, not to its equity base.

Our analysis begins by identifying the S\&P 100 firms that reported detailed regional breakdowns of sales for $1996-98 .^{2}$ We then estimate a model of each firm's weekly excess stock returns for the period 1997-98. We use the weekly excess return on the S\&P 500 as the relevant market factor because we want a broad measure for the market. Our model is based on the Capital Asset Pricing Model but extends it to allow for changes in betas, perhaps related to developments in Asia. ${ }^{3}$ Intuitively, betas may change in response to the Asian crisis or other shocks to the fundamentals of firms that are not shared to the same degree by the market as a whole.

We run a second-stage regression using results of the first-stage asset-pricing model as the dependent variable. We analyze the sensitivity of the firms' betas to the extent of their sales exposures to Asia, where sales are weighted by the ratio of long-term debt to total assets. We find that leverage-weighted sales exposure to Asia exerts a significant positive effect on a firm's CAPM beta.

\footnotetext{
${ }^{1}$ See Brealey and Myers (1996, pp. 160-64).

${ }^{2}$ We attempted but were not able to obtain a breakdown of sales by world regions for all of the S\&P 100 firms. Only 39 firms had sufficiently detailed information to be included in our sample.

${ }^{3}$ For a textbook presentation of the CAPM, see Brealey and Myers (1996, pp. 173-203). Jagannathan and Wang (1996) and others have developed the idea of a "conditional CAPM," that is, a period-by-period CAPM that allows betas to vary over time.
} 
Firms that had high sales exposure to Asia became more sensitive to movements in the S\&P 500 while firms with low sales exposure to the Asian region became less sensitive

\section{THE ASIAN CRISIS AND THE ROLE OF INCREASED BUSINESS RISK}

Following several decades of rapid economic growth and increasing integration into global capital markets, the economies of a number of Asian countries suffered abrupt and severe contractions during 1997 and 1998 (Economic Report of the President, 1999, pp. 227-51). The proximate cause of the crisis was a failed devaluation in Thailand, but recent analyses of the period have pointed to structural and especially financial-sector weaknesses in many of the affected countries. At the same time, a very large inflow of foreign capital during the early and mid-1990s, and the subsequent rapid withdrawal of many foreign investors during 1997 and 1998, exacerbated the adjustment process.

The reverberations of the Asian crisis on the world economy have been multifaceted. World economic growth slowed as the shortfall in demand from the Asian region caused both a severe regional recession and a deterioration in the trade balances of important trading partners such as the United States (Pollard and Coughlin, 1999). Commodity prices weakened, export competition increased in many sectors, and interest rates fell in the world's major economies. Industrial production slowed in many countries and corporate profits decelerated or declined.

Despite these disruptions, the U.S. economy grew strongly throughout the 1997-98 period. This experience has led some observers to conclude that the growth-enhancing consequences of the crisis for the United States - primarily lower interest rates and lower commodity prices-were simply more powerful than the growth-reducing factors, which included reduced demand for U.S. exports and financial losses suffered by lenders and investors in the region.

Another impact of the financial crisis was an increase in the observed volatility of financial markets and capital flows around the world. Figure 1 shows the sustained increase in stock-market volatility that occurred in the United States throughout 1997-98. The higher implied volatility of the S\&P 100 index during this period indicates that investor uncertainty about future stock-market returns had increased. In addition, capital flows to emerging markets collapsed while portfolio investments into the United States and other industrialized countries increased. These shifts in capital flows may go some way toward explaining the surge in U.S. and European stock-market price indexes during this period despite increased uncertainty about global economic growth and increased financial market volatility.

Figure 2 contrasts the divergent paths of U.S. and Asian emerging-market financial returns throughout this period. The cumulative total return during the two-year period on the S\&P 100 index of large-capitalization U.S. firms was an astonishing 71 percent, nearly 60 percentage points better than the risk-free return on three-month Treasury bills. Meanwhile, the dollar-denominated total return during the two years on the FT/S\&P Actuaries Pacific Stock-Market Index (excluding Japan) was about negative 42 percent. An investment in moneymarket instruments issued by Asian emerging-markets borrowers that was continually rolled over during 1997 and 1998 would have earned about a 2 percent total return in dollar terms, according to the J.P. Morgan Emerging Local Markets Index Plus (Asia).

The surge in U.S. stock prices is even more remarkable when one considers that after-tax earnings per share of the S\&P 500 companies actually fell during 1997 and 1998, and that corporate bond yield spreads - that is, the extra yield that corporate issuers were forced to pay to borrow in comparison to U.S. Treasury yields-rose considerably (see Figure 3). Although alternative explanations may exist, a single risk-based explanation of these phenomena-high stock returns and volatility, declining or flat profits, and increasing bond yield spreads-is plausible. In a nutshell, the main effect of the Asian crisis, which began in the second half of 1997 and spread to Russia in August 1998, may have been to increase the perceived riskiness of corporate cash flows.

To understand how investor perceptions of increased business risk could be responsible for high stock returns and volatility, as well as increased corporate bond yield spreads-all while earnings remain flat-we need to apply the "option-theoretic interpretation of the firm." 4 The key insight of this approach is that the equity of a firm that has issued debt (eg., bonds) is identical to a call option written on the assets of the firm, the ownership of which has been, in effect, transferred to the

\footnotetext{
${ }^{4}$ Black and Scholes (1973) is the original source of this interpretation of the corporate financial structure of every firm. Brealey and Myers (1996, pp. 564-66) provide a textbook discussion of these ideas.
} 
debtholders. When issuing a bond, the owners of a previously debt-free firm effectively sell the firm's assets to the bondholders and receive, in addition to the cash proceeds of the bond issue, a call option that gives them (the equityholders) the right-but not the obligation - to buy back the firm's assets by paying off the debt in full with interest. Thus, the bondholders will end up either with their money back (plus interest) or the firm itself, whichever is less valuable (because the choice is made by the equityholders). In the case of bankruptcy, the owners have decided that the firm is of less value to them as a going concern than the cash required to buy it back from its debtholders. The equityholders allow their call option to expire unexercised and "walk away" from the firm by virtue of limited liability.

How does this apply to the Asian crisis and the conjunction of high stock returns and increased corporate bond yield spreads during 1997 and 1998 ? One key determinant (among several) of the value of any option is the volatility of the underlying cash flows upon which the option is written. In the present application, the U.S. corporate sector generates cash flows for which corporate equityhol ders and corporate bondholders have claims. Precisely because the owner of an option has the right but not the obligation to exercise it, a greater dispersion of likely outcomes-i.e, higher risk - enhances the value of the option. The optionholder can capture all of the increased "upside" while ignoring all of the "downside," even if this has increased as well. This explains why stock prices could go up during the 1997-98 period even while corporate earnings were flat. Investors may have bid up stock prices because the range of future earnings estimates had increased (even if their expected level did not change). That is, the value of a call option on the assets of a firm increases when fundamental business risk increases.

Is there any other evidence that increased risk, rather than higher expected earnings, boosted stock returns during the Asian crisis? The behavior of corporate bond prices provides this evidence. The "dual" or complementary approach to corporate financial valuation within the option-theoretic interpretation of the firm can explain why corporate bond prices declined and yield spreads went up at the same time that stock prices went up. The dual approach points out the equivalence between the call-option interpretation presented above and a put-option interpretation that is relevant for corporate bondholders. In this interpretation, corporate
Figure 1

\section{Chicago Board Options Exchange S\&P 100 Volatility Index}

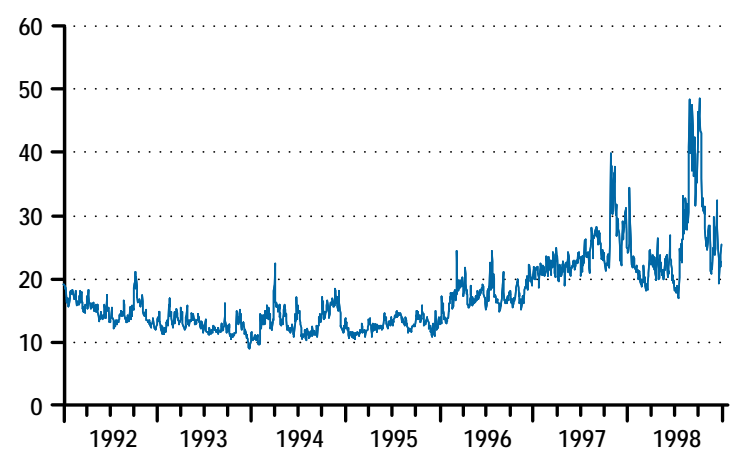

Source: Created using data from Chicago Board Options Exchange <http://www.cboe.com/tools/historical/vix.htm>.

Note: The vertical scale measures the implied annualized volatility (standard deviation) of the S\&P 100 derived from a hypothetical 30-day call option written on the S\&P 100 with strike price at the current day's market price, in percent.

\section{Figure 2}

\section{Total Return Indexes (in U.S. Dollar Terms)}

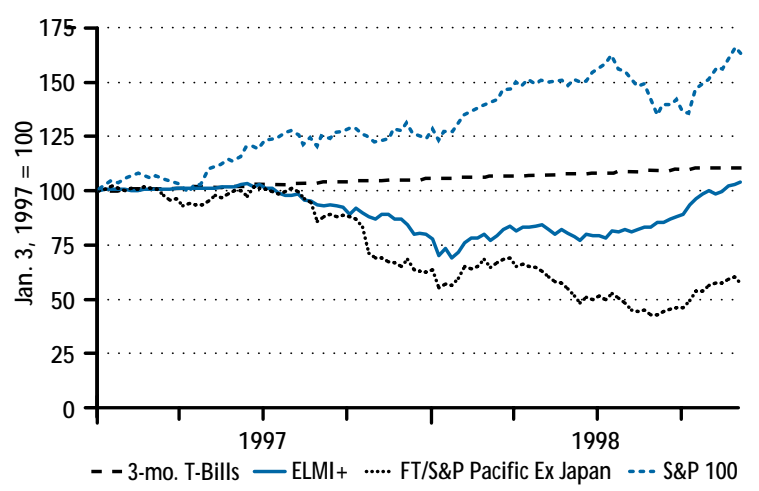

Data sources: The S\&P 100 return data were purchased from Standard \& Poor's Compustat. Data for calculating the three-month T-Bill return are from various editions of the Wall Street Journal. The Asian indices were purchased from J.P. Morgan and the FT/S\&P Actuaries, respectively.

bondholders effectively purchase an equivalent default-risk-free bond (i.e, identical in maturity and coupon rate) and underwrite a put option on the assets of the firm that is given to the equityholders. From the bondholders' perspective, the equityholders retain ownership of the firm's assets and are given the right to "put" (deliver) the assets of the firm to 


\section{Figure 3}

\section{Quarterly Corporate Earnings Growth and Corporate Bond Yield Spreads}

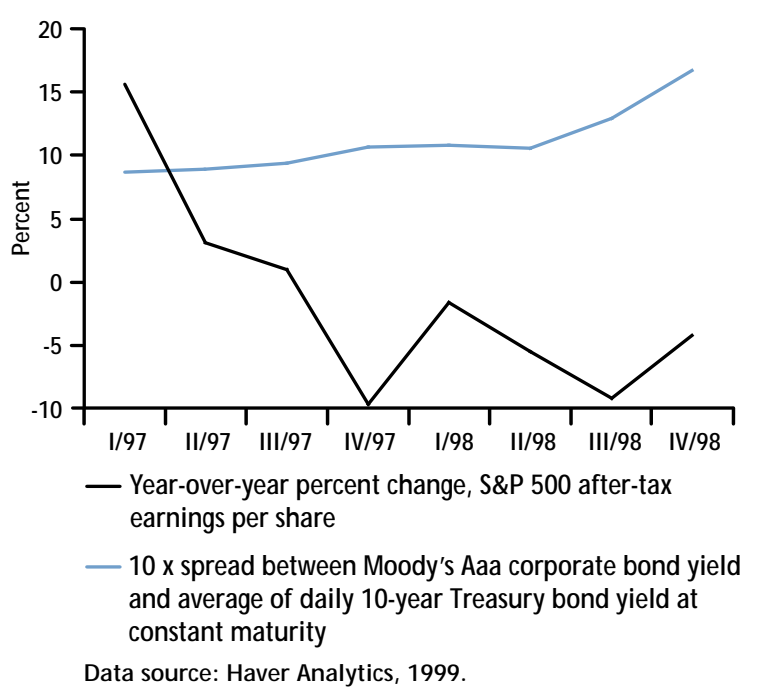

the bondholders in lieu of cash payment in satisfaction of the debt obligations.

Increased business risk means that the probability of default-situations when the assets are worth less than the debt they secure - has increased. Thus, increased business risk means that the put option underwritten by bondholders has become more valuable and consequently the value of the bonds has fallen. This implies that corporate bond yield spreads rise, as they did during the Asian crisis. Together, these option-theoretic interpretations of corporate securities can explain why high stock-market volatility, rising equity prices, and falling corporate bond prices-all while expected earnings have not changed-are perfectly consistent. The underlying shock was an increase in the riskiness of the corporate sector and the stock and bond price movements simply reflected a redistribution of firm value among claimholders. ${ }^{5}$

We would not expect that all firms' riskiness went up at the same time by the same amount. Instead, one would expect greater stock-price responses at firms with more exposure to the source of increased risk. In addition, one would expect a greater stock-price response at those firms that are more highly leveraged; this is because they are more likely to become bankrupt, all else being equal, so the option to default is more valuable. This article explores the firm-level changes in sys- tematic risk that may have been induced by the Asian crisis. Systematic risk is measured as the sensitivity of a firm to market-wide stock-price movements. Risk is measured relative to the market as a whole. Our goal is to isolate differences in firm responses to the Asian crisis rather than to measure the overall impact on market risk.

The empirical analysis of the article uses two total-return series as alternative proxies for the evolution and severity of the Asian crisis. Although they clearly reflect different asset and risk classes, these two total-return series present a similar picture of the timing of the onset of the crisis, roughly the middle of 1997. By way of contrast, the money-market index indicates that recovery from the crisis began in early 1998, while the stockmarket index did not turn upward decisively until the third quarter of 1998.

\section{THE ECONOMETRIC MODEL: FIRST-STAGE REGRESSION}

Our goal is to analyze the channel through which the Asian crisis affected the risk positions of U.S. firms during the period 1997-98. ${ }^{6}$ We use a two-stage regression approach because it makes interpretation of the results relatively straightforward. ${ }^{7}$ In the first-stage regression of our model, we provide evidence for the influence of the Asian crisis on the stock-market risk of the sample firms. For this purpose we set up the asset-pricing model with time-varying betas. We show that this model can be rewritten as a two-factor model, with a proxy for the Asian crisis appearing in the second factor. We provide evidence that the Asian crisis indeed affected the systematic risk of U.S. firms.

\section{First-Stage Estimation Procedure}

Our first-stage regression estimates a weekly asset-pricing model for each firm $i(i=1, \ldots, 39)$ for the period 1997-98. This model follows the CAPM but extends it in two ways to allow for time-varying $\beta$-coefficients. First, we allow the firm-specific

\footnotetext{
${ }^{5}$ Schmid (1999) provides a concise overview of the argument made here.

${ }^{6}$ All sample firms are headquartered in the United States with the exception of Northern Telecom (NORTEL) of Canada.

${ }^{7}$ Alternatively, we could estimate the model using a single-stage approach, as a later section describes briefly.
} 
parameters of the model to differ between 1997 and $1998 .^{8}$ Second, we allow the CAPM beta of each firm to depend on developments in Asia, which we proxy by two alternative measures of the excess dollar return on a portfolio invested in Asian securities.

The first-stage regression model is the following:

$$
\begin{aligned}
R_{i, t}-R_{f, t}= & \beta_{i, j}\left(1+\lambda_{i, j} \times \text { CRISIS }_{t}\right) \\
& \times\left(R_{m, \mathrm{t}}-R_{f, t}\right)+\varepsilon_{i, t}
\end{aligned}
$$

with $\mathrm{j}=1997$ for $\mathrm{t}=1, \ldots, 52$ and $\mathrm{j}=1998$ for $t=53, \ldots, 104$ (weeks running from the beginning of 1997 to the end of 1998). The dependent variable, $R_{i, t}-R_{f, t}$ is the excess log return in week $t$ on firm $i$ 's stock in period $t ; R_{f, t}$ is the risk-free rate, the one-week return on a three-month Treasury bill. $\mathrm{CRISIS}_{t}$ is a variable that proxies for the state of the Asian crisis in week $t ; R_{m, t}-R_{f, t}$ is the excess log return during week $t$ on the U.S. stock-market portfolio (S\&P 500); and $\varepsilon_{\mathrm{i}, \mathrm{t}}$ is the error term. The error term $\varepsilon_{i, t}$ measures realizations of the firm's idiosyncratic risk, that is, movements in the firm's excess return that are not explained by its comovement with the market.

The parameters of interest are $\beta_{i, j}$ and $\lambda_{i, j}$. It is important to recognize that it is the entire expression $\beta_{\mathrm{i}, \mathrm{j}}\left(1+\lambda_{\mathrm{i}, \mathrm{j}} \times \mathrm{CRISIS}_{\mathrm{t}}\right)$ that corresponds to the market beta of firm i in the standard CAPM framework (see Brealey and Myers, 1996, pp. 179-83). In purely statistical terms, the standard CAPM betaas well as our more complicated expression for beta-is the covariance of firm i's excess log return with the U.S. market excess log return, divided by the variance of the market excess log return. In interpreting our model, the parameter $\lambda_{\mathrm{i}, \mathrm{i}}$ is meant to capture the possible dependence of the CAPM beta estimated for firm i on the economic situation in Asia. We measure the current state of the Asian crisis as the weekly excess return on an Asian portfolio of securities. This is because we want to allow each firm's CAPM beta to be timevarying and to depend on investors' expectations about Asia and the particular firm's exposure to these developments.

Our time-varying extension of the CAPM model in equation 1 is nonlinear in the parameters. For ease of estimation we remove the nonlinearity by defining a new parameter, $\delta_{\mathrm{i}, \mathrm{j}}=\beta_{\mathrm{i}, \mathrm{j}} \lambda_{\mathrm{i}, \mathrm{j}}$, and rewriting equation 1 as follows:

$$
\begin{aligned}
R_{i, t}-R_{f, t}= & \beta_{i, j}\left(R_{m, t}-R_{f, t}\right)+\delta_{i, j} \\
& \times C R I S I S_{t} \times\left(R_{m, t}-R_{f, t}\right)+\varepsilon_{i, t}
\end{aligned}
$$

again with $\mathrm{j}=1997$ for $\mathrm{t}=1, \ldots, 52$ and $\mathrm{j}=1998$ for $t=53, \ldots, 104$. The firm's exposure to market movements, its CAPM or market beta, can now be seen to contain two components: An autonomous (not crisis-related) component, $\beta \mathrm{i}, \mathrm{j}$, and a crisis-sensitive component, $\delta_{i, j} \times \mathrm{CRISIS}_{\mathrm{t}}$. The evolution of a firm's CAPM beta, therefore, is allowed to depend on developments in Asia in an easily estimable way. ${ }^{9}$

It also is possible to interpret model 2 not solely as a time-varying extension of the (one-factor) CAPM but as a multifactor asset-pricing model (Merton, 1973; Ross, 1976; Fama and French, 1992; Campbell and Cochrane, 1999). ${ }^{10}$ This interpretation is valid only if the two "factors" represented by the U.S. market excess return and the product of the Asian and U.S. market excess returns essentially are uncorrelated. It turns out in our sample that they are: The pair-wise correlations of the two independent variables are -0.155 and -0.173 for the two crisis proxies that we investigate. Thus, we also can interpret our results as estimates of the sensitivity of firms' excess returns to first, U.S. excess market returns, and second, the product of Asian and U.S. excess market returns. If the two factors were completely uncorrelated, the estimated coefficient on the first (non-time varying component) would, in fact, be the (unconditional) CAPM beta.

We use weekly observations of returns from the beginning of 1997 through the end of 1998 to estimate the model. We examine two alternative crisis variables, each of which is the excess log return (in dollar terms) on an Asian portfolio,

\footnotetext{
${ }^{8}$ We chose one-year windows because the firm characteristics of interest in our second-stage regression are observed annually. At the same time, one-year windows allow for a sufficient number of weekly observations for the estimation of the parameters of interest in the asset-pricing model.

${ }^{9}$ An increase in the firm's exposure to market risk has two effects on the parameter $\delta_{\mathrm{i}, \mathrm{j}}$. First, investors demand higher future returns, which causes $\delta_{i, j}$ to increase. Second, an increase in $\delta_{i, j}$ implies that, for given expected future cash flows, the firm's stock price will decline initially. This reinforces the comovement of the firm's stock with the crisis variable.

${ }^{10}$ Campbell and Cochrane (1999, p. 7) demonstrate the equivalence of a one-factor conditional CAPM and an unconditional multifactor CAPM in which the two factors are the excess market return and the product of the excess market return and a time-varying predetermined financial variable (the log dividend-price ratio in their case). In our case, the financial variable is the value of an Asian-crisis proxy.
} 
$R_{\text {Asia }}-R_{f}$, where the risk-free return $R_{f}$, is the weekly return on the three-month U.S. Treasury bill. The first crisis variable we use is the excess log return on the FT/S\&P Actuaries Pacific StockMarket Index excluding Japan. The second crisis variable is the excess log return on the J.P. Morgan Emerging Local Markets Index Plus (Asia), an index of money-market securities issued in Asian emerging markets. ${ }^{11}$

We assume $\operatorname{Cov}\left[\varepsilon_{i, t}, \varepsilon_{i, s}\right]=0$ for $t \neq s$, where $\mathrm{t}, \mathrm{s}=1, \ldots, \mathrm{T}$, that is, the error terms are serially uncorrelated. We allow the error terms to be heteroskedastic across equations (i.e., firms) but not over time. This means that $\operatorname{Var}\left[\varepsilon_{i, t}\right]=\sigma_{i}^{2}$ need not be identical for all i $(i=1, \ldots, N)$ but they are assumed to be identical for all $t(t=1, \ldots, T) .^{12}$ We adopt the seemingly unrelated regression (SUR) approach but impose a diagonal covariance matrix for the error terms. That is, for all $\mathrm{t}(\mathrm{t}=$ $1, \ldots, T)$, we impose the restriction $\operatorname{Cov}\left[\varepsilon_{\mathrm{i}, \mathrm{t}}, \varepsilon_{\mathrm{j}, \mathrm{t}}\right]=$ $0, i \neq j(i, j=1, \ldots, N)$. This restriction is appropriate because regressors are identical across the set of firm-specific regression equations that are used in the regression model $2 .^{13}$

We test for serial correlation using the LjungBox (1978) test statistic with a standard lag length of floor $\left(4(T / 100)^{2 / 9}\right)$, where floor means rounded down to the nearest integer. The null hypothesis of no serial correlation could not be rejected. We used the heteroskedasticity-consistent covariance matrix proposed by White (1980). Both the t-tests and the Wald tests are based on heteroskedasticityconsistent standard errors. ${ }^{14}$ The White correction procedure deals with heteroskedastic residuals in the most general way. In estimating equation 2 , the procedure controls for any form of heteroskedasticity that goes beyond the cross-sectional differences in the variances $\sigma_{1}^{2}(i=1, \ldots, N)$ for which the model controls directly. 15

\section{Results of First-Stage Regression}

Although a larger sample size would have been desirable, we were able to obtain reliable geographical breakdowns of sales data for only 39 of the S\&P 100 firms (see Tables 1 and 2 for the list of firms, their sales exposures to Asia, their financial leverage, and sample statistics for these variables). We obtained total-return series and calculated weekly excess returns (i.e, the return in excess of the return on a three-month T-bill) for each firm's stock and for the following (all in U.S. dollar terms): the S\&P 500 index; the FT/S\&P Actuaries World Stock-Market Index Pacific excluding Japan; and the J.P. Morgan Emerging Local Markets Index Plus (Asia), a moneymarket return index. ${ }^{16}$ The cumulative total U.S. dollar returns for these three risky portfolios and for the riskless T-bill are plotted in Figure 2.

Estimates of the "autonomous" part of each firm's market sensitivity. The estimated coefficients, $\hat{\beta}_{\mathrm{i}, 1997}$ and $\hat{\beta}_{\mathrm{i}, 1998}$, would retain their interpretation from the traditional one-period CAPM framework as measures of the comovement of the excess return of firm i with the only relevant (priced) factor - the excess return of the market (the S\&P 500 ) in year $j$-only under the null hypothesis that there is no crisis-related time variation in this factor loading (i.e., estimated sensitivity). If there is some systematic relationship between movements in our proxies for the Asian crisis and the way the stockmarket prices our sample firms' equity returns, however, then our beta coefficients will quantify only the "autonomous component" of firms' exposures to market risk. Table 3, which appears on page 24, displays our estimated autonomous $\beta$-coefficients, where we have used the excess log returns on the FT/S\&P Asian stock-market index in the first two columns and the excess log returns on the J.P. Morgan money-market index in the last two columns, respectively, as a proxy for the Asian crisis.

Estimated autonomous $\beta$-coefficients generally are significant statistically in Table 3 , with 73 of 78 coefficients significant at the 10-percent level when using the Asian stock-market index. The Wald statistic for the overall fit of the 39-equation system of estimated $\beta$-coefficients is significant statistically in each year, as well. Significant Wald statistics for tests of cross-sectional and intertemporal differences indicate that there is a great deal of firm heterogeneity and intertemporal variation with respect

\footnotetext{
${ }^{11}$ For a list of the variables employed in this paper, see Appendix B.

${ }^{12}$ We control for the effects of a possible violation of the assumption of time-invariant variances by using White's (1980) heteroskedasticityconsistent covariance matrix.

${ }^{13}$ In this case, accounting for potential contemporaneous correlation across equations offers no efficiency gain. See Greene (1997, p. 676).

${ }^{14}$ See Greene (1997, p. 488) on how to implement covariance matrices for nonspherical disturbances in Wald tests.

${ }^{15}$ This implies that the White-corrected standard errors in the SUR framework are identical to those that would result if the equations in model 2 were White-corrected individually.

${ }^{16}$ See Appendix A for a detailed data description.
} 


\section{Table 1}

\section{Sample Firms}

Panel A: Industry Classifications

\begin{tabular}{|c|c|c|c|}
\hline Firm & $\begin{array}{l}\text { Ticker } \\
\text { Symbol }\end{array}$ & $\begin{array}{l}\text { SIC } \\
\text { Code }\end{array}$ & Primary Industry Classification \\
\hline Aluminum Company of America & AA & 33 & Primary Metal Industries \\
\hline American Express Company & AXP & 61 & Nondepository Financial Institutions \\
\hline AMP Incorporated & AMP & 36 & Electronic \& Electric Equipment \\
\hline Avon Products, Inc. & AVP & 28 & Chemicals \& Related Products \\
\hline BankAmerica Corporation & BAC & 60 & Banks \& Banking Services \\
\hline Baxter International, Inc. & BAX & 38 & Instruments \& Related Products \\
\hline Boeing Company & $\mathrm{BA}$ & 37 & Transportation Equipment \\
\hline Bristol-Myers Squibb Company & BMY & 28 & Chemicals \& Related Products \\
\hline Champion International Corporation & $\mathrm{CHA}$ & 26 & Paper \& Related Products \\
\hline Coca Cola Company & KO & 20 & Food \& Related Products \\
\hline Computer Sciences Corporation & $\operatorname{CsC}$ & 73 & Business Services \\
\hline Delta Air Lines, Inc. & DAL & 45 & Air Transportation \\
\hline Eastman Kodak Company & EK & 38 & Instruments \& Related Products \\
\hline Fluor Corporation & FLR & 16 & Heavy Construction \\
\hline General Electric Company & GE & 36 & Electronic \& Electric Equipment \\
\hline General Motors Corporation & GM & 37 & Transportation Equipment \\
\hline H.J. Heinz Company & HNZ & 20 & Food \& Related Products \\
\hline Halliburton Company & HAL & 16 & Heavy Construction \\
\hline Homestake Mining Company & HM & 10 & Metal Mining \& Related Services \\
\hline Intel Corporation & INTC & 36 & Electronic \& Electric Equipment \\
\hline International Business Machines Corporation & IBM & 35 & Industrial Equipment \& Machinery \\
\hline International Paper Company & IP & 26 & Paper $\&$ Related Products \\
\hline Johnson \& Johnson & $J N J$ & 28 & Chemicals \& Related Products \\
\hline Mallinckrodt, Inc. & MKG & 28 & Chemicals \& Related Products \\
\hline McDonald's Corporation & MCD & 58 & Dining \& Drinking Places \\
\hline Merck \& Co., Inc. & MRK & 28 & Chemicals \& Related Products \\
\hline Merrill Lynch \& Co., Inc. & MER & 62 & Security \& Commodity Brokers \\
\hline Minnesota Mining \& Manufacturing Company & MMM & 32 & Stone, Clay $\&$ Glass Products \\
\hline Mobil Corporation & MOB & 29 & Petroleum \& Coal Products \\
\hline Monsanto Company & MTC & 28 & Chemicals \& Related Products \\
\hline National Semiconductor Corporation & NSM & 36 & Electronic \& Electric Equipment \\
\hline Northern Telecom Limited & NT & 36 & Electronic \& Electric Equipment \\
\hline Oracle Corporation & ORCL & 73 & Business Services \\
\hline PepsiCo, Inc. & PEP & 20 & Food \& Related Products \\
\hline Pharmacia \& Upjohn, Inc. & PNU & 28 & Chemicals \& Related Products \\
\hline Ralston-Purina Company & RAL & 20 & Food \& Related Products \\
\hline Schlumberger Limited & SLB & 13 & Oil \& Gas Production \\
\hline United Technologies Corporation & UTX & 37 & Transportation Equipment \\
\hline Xerox Corporation & XRX & 38 & Instruments \& Related Products \\
\hline
\end{tabular}


Table 1

Sample Firms

Panel B: Values of the Variables SALES and DEBT

\begin{tabular}{|c|c|c|c|c|}
\hline Firm & $\begin{array}{c}\text { SALES } \\
1996 \\
\end{array}$ & $\begin{array}{l}\text { SALES } \\
1997 \\
\end{array}$ & $\begin{array}{l}\text { DEBT } \\
1996 \\
\end{array}$ & $\begin{array}{l}\text { DEBT } \\
1997 \\
\end{array}$ \\
\hline Aluminum Company of America & 0.172 & 0.167 & 0.126 & 0.111 \\
\hline American Express Company & 0.083 & 0.078 & 0.060 & 0.066 \\
\hline AMP Incorporated & 0.193 & 0.198 & 0.039 & 0.033 \\
\hline Avon Products, Inc. & 0.156 & 0.154 & 0.047 & 0.045 \\
\hline BankAmerica Corporation & 0.092 & 0.079 & 0.062 & 0.054 \\
\hline Baxter International, Inc. & 0.164 & 0.145 & 0.223 & 0.303 \\
\hline Boeing Company & 0.335 & 0.301 & 0.146 & 0.161 \\
\hline Bristol-Myers Squibb Company & 0.104 & 0.098 & 0.066 & 0.085 \\
\hline Champion International Corporation & 0.000 & 0.000 & 0.314 & 0.351 \\
\hline Coca Cola Company & 0.218 & 0.226 & 0.069 & 0.047 \\
\hline Computer Sciences Corporation & 0.055 & 0.062 & 0.156 & 0.176 \\
\hline Delta Air Lines, Inc. & 0.028 & 0.024 & 0.147 & 0.116 \\
\hline Eastman Kodak Company & 0.154 & 0.160 & 0.039 & 0.045 \\
\hline Fluor Corporation & 0.095 & 0.108 & 0.001 & 0.064 \\
\hline General Electric Company & 0.045 & 0.043 & 0.181 & 0.153 \\
\hline General Motors Corporation & 0.021 & 0.009 & 0.176 & 0.186 \\
\hline H.J. Heinz Company & 0.119 & 0.121 & 0.265 & 0.271 \\
\hline Halliburton Company & 0.158 & 0.166 & 0.045 & 0.096 \\
\hline Homestake Mining Company & 0.192 & 0.379 & 0.125 & 0.202 \\
\hline Intel Corporation & 0.302 & 0.289 & 0.031 & 0.016 \\
\hline International Business Machines Corporation & 0.194 & 0.194 & 0.122 & 0.168 \\
\hline International Paper Company & 0.112 & 0.106 & 0.237 & 0.267 \\
\hline Johnson \& Johnson & 0.123 & 0.128 & 0.070 & 0.052 \\
\hline Mallinckrodt, Inc. & 0.077 & 0.053 & 0.169 & 0.182 \\
\hline McDonald's Corporation & 0.119 & 0.133 & 0.278 & 0.265 \\
\hline Merck \& Co., Inc. & 0.089 & 0.074 & 0.048 & 0.052 \\
\hline Merrill Lynch \& Co., Inc. & 0.062 & 0.062 & 0.123 & 0.147 \\
\hline Minnesota Mining \& Manufacturing Company & 0.181 & 0.175 & 0.064 & 0.077 \\
\hline Mobil Corporation & 0.217 & 0.259 & 0.096 & 0.084 \\
\hline Monsanto Company & 0.069 & 0.087 & 0.144 & 0.184 \\
\hline National Semiconductor Corporation & 0.337 & 0.338 & 0.132 & 0.111 \\
\hline Northern Telecom Limited & 0.074 & 0.070 & 0.153 & 0.125 \\
\hline Oracle Corporation & 0.143 & 0.142 & $0.000 *$ & 0.065 \\
\hline PepsiCo, Inc. & 0.116 & 0.066 & 0.344 & 0.246 \\
\hline Pharmacia \& Upjohn, Inc. & 0.146 & 0.137 & 0.051 & 0.038 \\
\hline Ralston-Purina Company & 0.148 & 0.119 & 0.300 & 0.392 \\
\hline Schlumberger Limited & 0.295 & 0.315 & 0.062 & 0.088 \\
\hline United Technologies Corporation & 0.129 & 0.119 & 0.086 & 0.076 \\
\hline Xerox Corporation & 0.006 & 0.006 & 0.314 & 0.317 \\
\hline
\end{tabular}

$*$ Zero value is due to rounding. 
FEDERAL RESERVE BANK Of ST. LOUIS

\section{Table 2}

Summary Statistics for SALES and DEBT

\begin{tabular}{lccccc}
1996 & Minimum & Median & Mean & Maximum & $\begin{array}{c}\text { Standard } \\
\text { Deviation }\end{array}$ \\
\hline SALES & 0 & 0.123 & 0.136 & 0.337 & 0.083 \\
& 0 & 0.121 & 0.138 & 0.379 & 0.094 \\
DEBT & 0 & 0.123 & 0.131 & 0.344 & 0.093 \\
& 0.016 & 0.111 & 0.141 & 0.392 & 0.098 \\
\hline
\end{tabular}

to market risk exposures of large firms. Results are similar when excess log returns on the J.P. Morgan money-market index are used as the crisis proxy. We also tested the significance of firm-specific intercepts in model 2. Wald test statistics of 37.60 (for the stock-market index) and 34.98 (for the money-market index) indicate that firm-specific intercepts are - as a group—not significant statistically, and thus, are excluded from the regression equation.

Estimates of $\delta$ and the "crisis-sensitive" components of firms' market sensitivity. The first-stage regression produces estimates of $\delta$ for each firm i during each year, $\hat{\delta}_{i, 1997}$ and $\hat{\delta}_{\mathrm{i}, 1998}(\mathrm{i}=$ $1, \ldots, 39)$. It is important to note that our proxy variables for the Asian crisis are negative, on average, during 1997 and 1998 for the FT/S\&P stock-market index and during 1997 for the money-market index. Therefore, to translate the regression coefficients into a measure of the influence of the Asian crisis on the $\beta$-coefficients, we multiply $\hat{\delta}_{\mathrm{i}, 1997}$ and $\hat{\delta}_{\mathrm{i}, 1998}$ by the mean of the Asian crisis variable during the respective year. The products of the means and the respective regression coefficients are displayed in Table 4. They are estimates of the "crisis-sensitive" component of the firm's CAPM beta.

Table 4 indicates that 23 of the 78 estimates of a possible crisis-sensitive component of firm exposures to market risk were different from zero at the 10-percent confidence level when the Asian stockmarket index was used as the crisis proxy. This is about three times as many as would be expected by pure chance. When the Asian money-market index was used as the crisis proxy, 20 of 78 estimates were significant at the 10-percent level. Thus, we conclude that it is possible to split large firms' exposures to market risk (their CAPM betas) into autonomous and crisis-sensitive components. As in the systems of estimated autonomous betas discussed above, the Wald statistics all are significant statistically in tests for the over-all fit of the crisissensitive components model, as well as for cross-sectional and intertemporal differences in crisis-sensitive components in firm returns.

By adding the crisis-sensitive component of a firm's beta from Table 4 to its corresponding autonomous part, presented in Table 3, we obtain the average total sensitivity of the firm to the S\&P 500 return. This is the firm's beta measured at the mean of the respective crisis variable. Table 5, which appears on page 26 , provides summary statistics that condense the information presented in Tables 3 and 4.

It is important to note that the sensitivity of the excess log return of firms we examine are unlikely to increase (or decrease) all at the same time. This is because a firm's beta measures the position of this firm relative to the index. ${ }^{17}$ For example, if we had the entire set of S\&P 500 firms in our sample, some betas necessarily would decrease if others increased. If greater sales exposure to Asia added to the firm's sensitivity to market risk, the betas of the firms that have a higher-than-average fraction of their sales to Asia would increase in response to the crisis while betas of those firms with below-average sales to Asia would have to decrease. The index average corresponds to the S\&P 500's "average" firm.

Using the FT/S\&P index returns in Tables 3 and 4, for example, we estimate the components of Minnesota Mining and Manufacturing's (3M) average total U.S. market (i.e, S\&P 500) sensitivity during 1997 to be 0.497 and 0.111 , for a total of

\footnotetext{
${ }^{17} \mathrm{~A}$ common influence of the Asian crisis on all firms' contributions to market risk would not lead to changes in the firms' betas. This is because a common impact (by definition) would affect all firms equally, leaving their positions relative to the market index unchanged.
} 
Table 3

Estimates of the Autonomous Component of CAPM Betas, $\beta_{\mathrm{i}, \mathrm{j}}$

\begin{tabular}{|c|c|c|c|c|}
\hline \multirow[b]{2}{*}{ Firm } & \multicolumn{2}{|c|}{ Asian Stock-Market Index } & \multicolumn{2}{|c|}{ Asian Money-Market Index } \\
\hline & 1997 & 1998 & 1997 & 1998 \\
\hline Aluminum Company of America & $0.810 * * *$ & $0.640 * * *$ & $0.764 * * *$ & $0.659 * * *$ \\
\hline American Express Company & $1.229 * * *$ & $1.778 * * *$ & $1.297 * * *$ & $1.785^{* * *}$ \\
\hline AMP Incorporated & $1.152 * * *$ & 0.095 & $0.850 * * *$ & 0.124 \\
\hline Avon Products, Inc. & $0.733^{* *}$ & $1.397 * * *$ & $1.004^{* * *}$ & $1.384 * * *$ \\
\hline BankAmerica Corporation & $0.817^{* * *}$ & $1.245^{* * *}$ & $1.057 * * *$ & $1.232^{* * *}$ \\
\hline Baxter International, Inc. & $1.113 * * *$ & $0.541 * * *$ & $1.041 * * *$ & $0.523 * * *$ \\
\hline Boeing Company & $0.307 *$ & $1.187 * * *$ & 0.252 & $1.215^{* * *}$ \\
\hline Bristol-Myers Squibb Company & $1.181^{* * *}$ & $0.945^{* * *}$ & $1.241 * * *$ & $0.946 * * *$ \\
\hline Champion International Corporation & $0.783 * * *$ & $1.336 * * *$ & $0.814 * * *$ & $1.333^{* * *}$ \\
\hline Coca Cola Company & $1.381 * * *$ & $1.085^{* * *}$ & $1.377 * * *$ & $1.083 * * *$ \\
\hline Computer Sciences Corporation & $1.097 * * *$ & $0.788 * *$ & $0.667 *$ & $0.781 * *$ \\
\hline Delta Air Lines, Inc. & $1.033 * * *$ & $1.203 * * *$ & $0.925 * * *$ & $1.184^{* * *}$ \\
\hline Eastman Kodak Company & $0.721 * *$ & 0.077 & $0.555^{*}$ & 0.087 \\
\hline Fluor Corporation & $0.949 * * *$ & $1.198 * * *$ & $1.070 * * *$ & $1.184 * * *$ \\
\hline General Electric Company & $1.111 * * *$ & $1.351 * * *$ & $1.242 * * *$ & $1.334 * * *$ \\
\hline General Motors Corporation & $0.827 * * *$ & $1.112 * * *$ & $0.813 * * *$ & $1.117 * * *$ \\
\hline H.J. Heinz Company & $0.892 * * *$ & $1.818 * * *$ & $0.592 *$ & $1.858 * * *$ \\
\hline Halliburton Company & $1.051^{* * *}$ & $0.508 * * *$ & $0.921 * * *$ & $0.505^{* * *}$ \\
\hline Homestake Mining Company & 0.261 & 0.353 & 0.273 & 0.408 \\
\hline Intel Corporation & $1.074 * * *$ & $0.642^{* *}$ & $0.988 * * *$ & $0.637 * * *$ \\
\hline International Business Machines Corporation & $0.897 * * *$ & $0.816 * * *$ & $0.729 * * *$ & $0.828 * * *$ \\
\hline International Paper Company & $0.901 * * *$ & $0.753^{* * *}$ & $1.147 * * *$ & $0.764 * * *$ \\
\hline Johnson \& Johnson & $1.035^{* * *}$ & $0.485^{* * *}$ & $1.218^{* * *}$ & $0.470 * * *$ \\
\hline Mallinckrodt, Inc. & $0.290^{*}$ & $0.807 * * *$ & $0.391 * *$ & $0.810^{* * *}$ \\
\hline McDonald's Corporation & $0.614 * * *$ & $0.941 * * *$ & $0.589 * * *$ & $0.953 * * *$ \\
\hline Merck \& Co., Inc. & $1.188^{* * *}$ & $0.858 * * *$ & $1.135 * * *$ & $0.866 * * *$ \\
\hline Merrill Lynch \& Co., Inc. & $1.928 * * *$ & $2.055^{* * *}$ & $1.990 * * *$ & $2.052 * * *$ \\
\hline Minnesota Mining \& Manufacturing Company & $0.497 * * *$ & $0.650 * * *$ & $0.578 * * *$ & $0.635^{* * *}$ \\
\hline Mobil Corporation & $0.916^{* * *}$ & $0.680 * * *$ & $1.011 * * *$ & $0.712^{* * *}$ \\
\hline Monsanto Company & $0.829 * * *$ & 0.789 & $0.727 * *$ & 0.781 \\
\hline National Semiconductor Corporation & $1.467 * * *$ & $1.039 * *$ & $1.252 * * *$ & $1.077^{* *}$ \\
\hline Northern Telecom Limited & $1.450 * * *$ & $1.604^{* * *}$ & $1.348 * * *$ & $1.602 * * *$ \\
\hline Oracle Corporation & $0.774^{*}$ & $1.844 * * *$ & 0.383 & $1.885^{* * *}$ \\
\hline PepsiCo, Inc. & $0.785^{* * *}$ & $0.367 *$ & $0.698 * *$ & $0.386 * *$ \\
\hline Pharmacia \& Upjohn, Inc. & $0.981^{* * *}$ & $0.807 * * *$ & $0.924 * * *$ & $0.806 * * *$ \\
\hline Ralston-Purina Company & $0.857^{* * *}$ & $0.787 * * *$ & $0.803 * * *$ & $0.799 * * *$ \\
\hline Schlumberger Limited & $1.065^{* * *}$ & $1.563 * * *$ & $0.745^{* * *}$ & $1.588 * * *$ \\
\hline United Technologies Corporation & $0.803^{* * *}$ & $1.160 * * *$ & $0.746 * * *$ & $1.161^{* * *}$ \\
\hline Xerox Corporation & $0.973^{* * *}$ & $0.981 * * *$ & $0.728 * * *$ & $0.988 * * *$ \\
\hline Wald statistic & $1122 * * *$ & $916.2^{* * *}$ & $770.1 * * *$ & $930.1 * * *$ \\
\hline Wald statistic (cross-sectional differences) & $119.2 * * *$ & $139.5^{* * *}$ & $92.80 * * *$ & $136.7 * * *$ \\
\hline Wald statistic (intertemporal differences) & \multicolumn{2}{|c|}{$74.86 * * *$} & \multicolumn{2}{|c|}{$66.49 * * *$} \\
\hline Observations per firm & 52 & 52 & 52 & 52 \\
\hline
\end{tabular}




\section{Table 4}

Estimates of the Crisis-Sensitive Component of CAPM Betas, $\delta_{\mathrm{i}, \mathrm{j}} \times$ CRISIS, $_{\mathbf{t}}$ at Annual Means of CRISIS

\begin{tabular}{|c|c|c|c|c|}
\hline \multirow[b]{2}{*}{ Firm } & \multicolumn{2}{|c|}{ Asian Stock-Market Index } & \multicolumn{2}{|c|}{ Asian Money-Market Index } \\
\hline & 1997 & 1998 & 1997 & 1998 \\
\hline Aluminum Company of America & 0.043 & $0.012 * *$ & 0.046 & -0.031 \\
\hline American Express Company & -0.097 & 0.005 & -0.085 & -0.011 \\
\hline AMP Incorporated & 0.100 & 0.001 & $0.211^{* * *}$ & -0.032 \\
\hline Avon Products, Inc. & 0.112 & -0.007 & -0.088 & 0.020 \\
\hline BankAmerica Corporation & 0.057 & 0.020 & $-0.099 *$ & -0.001 \\
\hline Baxter International, Inc. & $0.074^{*}$ & $-0.012^{* * *}$ & $0.075^{*}$ & $0.029 * *$ \\
\hline Boeing Company & $0.171^{* * *}$ & $0.026 * *$ & 0.114 & $-0.051^{*}$ \\
\hline Bristol-Myers Squibb Company & $-0.104 * *$ & 0.002 & -0.084 & -0.003 \\
\hline Champion International Corporation & 0.150 & 0.008 & 0.059 & -0.004 \\
\hline Coca Cola Company & -0.010 & 0.008 & -0.003 & -0.004 \\
\hline Computer Sciences Corporation & -0.045 & -0.002 & $0.206^{* *}$ & 0.009 \\
\hline Delta Air Lines, Inc. & $-0.169 * *$ & $-0.009 *$ & -0.027 & $0.029 * *$ \\
\hline Eastman Kodak Company & 0.044 & $0.019 *$ & 0.110 & -0.025 \\
\hline Fluor Corporation & 0.027 & $-0.010 *$ & -0.051 & 0.024 \\
\hline General Electric Company & 0.017 & $-0.011 * *$ & $-0.061^{*}$ & $0.028 *$ \\
\hline General Motors Corporation & -0.009 & -0.007 & 0.003 & 0.000 \\
\hline H.J. Heinz Company & -0.062 & 0.004 & 0.128 & -0.048 \\
\hline Halliburton Company & -0.074 & 0.000 & 0.032 & 0.003 \\
\hline Homestake Mining Company & 0.077 & 0.019 & 0.032 & $-0.076^{*}$ \\
\hline Intel Corporation & $0.108 *$ & -0.007 & 0.100 & 0.010 \\
\hline International Business Machines Corporation & $0.155^{* *}$ & -0.001 & $0.167 * *$ & -0.012 \\
\hline International Paper Company & 0.124 & $0.006^{* *}$ & -0.068 & $-0.018^{*}$ \\
\hline Johnson \& Johnson & 0.052 & $-0.010^{*}$ & -0.071 & $0.024^{*}$ \\
\hline Mallinckrodt, Inc. & -0.023 & -0.001 & $-0.065 *$ & -0.003 \\
\hline McDonald's Corporation & $0.080 *$ & 0.005 & 0.053 & -0.017 \\
\hline Merck \& Co., Inc. & -0.026 & 0.002 & 0.016 & -0.011 \\
\hline Merrill Lynch \& Co., Inc. & $-0.066 * *$ & $0.019 * *$ & -0.066 & -0.012 \\
\hline Minnesota Mining \& Manufacturing Company & $0.111^{* * *}$ & $-0.008^{*}$ & 0.013 & $0.023^{* *}$ \\
\hline Mobil Corporation & $-0.057 * * *$ & $0.013^{* *}$ & $-0.079 * * *$ & $-0.046 * * *$ \\
\hline Monsanto Company & -0.060 & 0.025 & 0.024 & -0.011 \\
\hline National Semiconductor Corporation & 0.136 & 0.016 & 0.182 & -0.055 \\
\hline Northern Telecom Limited & 0.010 & -0.011 & 0.059 & 0.011 \\
\hline Oracle Corporation & 0.340 & 0.013 & 0.378 & -0.055 \\
\hline PepsiCo, Inc. & 0.043 & 0.010 & 0.068 & $-0.029 *$ \\
\hline Pharmacia \& Upjohn, Inc. & 0.002 & 0.000 & 0.031 & 0.001 \\
\hline Ralston-Purina Company & -0.027 & 0.012 & 0.015 & -0.023 \\
\hline Schlumberger Limited & -0.023 & 0.006 & $0.158 * *$ & -0.032 \\
\hline United Technologies Corporation & 0.070 & 0.002 & 0.065 & -0.002 \\
\hline Xerox Corporation & 0.026 & $0.010 *$ & $0.143 * *$ & -0.016 \\
\hline Wald statistic & $91.21 * * *$ & $72.72 * * *$ & $77.04 * * *$ & $67.03 * * *$ \\
\hline Wald statistic (cross-sectional differences) & $87.13^{* * *}$ & $71.95^{* * *}$ & $76.89 * * *$ & $65.37 * * *$ \\
\hline Wald statistic (intertemporal differences) & & & & \\
\hline Observations per firm & 52 & 52 & 52 & 52 \\
\hline
\end{tabular}

$* / * * / * * *$ significant at 10/5/1 percent levels (t-tests are two-tailed); tests refer to the actual regression coefficients, not to the displayed products between the regression coefficients and the annual means of the crisis variable. 
Table 5

\section{Summary of Results from First-Stage Regressions}

\begin{tabular}{|c|c|c|c|c|c|c|}
\hline $\begin{array}{l}1997 \\
1998\end{array}$ & $\begin{array}{l}\text { Asian-Crisis } \\
\text { Index }\end{array}$ & Minimum & Median & Mean & Maximum & $\begin{array}{l}\text { Standard } \\
\text { Deviation }\end{array}$ \\
\hline \multirow{4}{*}{$\begin{array}{l}\text { Autonomous } \\
\text { component of } \\
\text { CAPM beta, } \beta_{\mathrm{i}, \mathrm{j}}\end{array}$} & \multirow[t]{2}{*}{ Stock market } & $1.78 \times 10^{-1}$ & $9.18 \times 10^{-1}$ & $9.09 \times 10^{-1}$ & 1.72 & $3.17 \times 10^{-1}$ \\
\hline & & $1.35 \times 10^{-1}$ & $8.86 \times 10^{-1}$ & $9.49 \times 10^{-1}$ & 1.97 & $4.45 \times 10^{-1}$ \\
\hline & \multirow[t]{2}{*}{ Money market } & $2.13 \times 10^{-1}$ & $8.42 \times 10^{-1}$ & $8.82 \times 10^{-1}$ & 1.81 & $3.51 \times 10^{-1}$ \\
\hline & & $1.50 \times 10^{-1}$ & $8.87 \times 10^{-1}$ & $9.55 \times 10^{-1}$ & 1.98 & $4.45 \times 10^{-1}$ \\
\hline \multirow{4}{*}{$\begin{array}{l}\text { Crisis-sensitive } \\
\text { component of } \\
{\text { CAPM beta, } \delta_{i, j} \times} \times \\
\text { CRISIS }_{\mathrm{t}} \text {, (at annual } \\
\text { means of crisis } \\
\text { index) }\end{array}$} & \multirow[t]{2}{*}{ Stock market } & $-1.49 \times 10^{-1}$ & $2.09 \times 10^{-2}$ & $1.86 \times 10^{-2}$ & $2.92 \times 10^{-1}$ & $8.25 \times 10^{-2}$ \\
\hline & & $-1.35 \times 10^{-2}$ & $2.47 \times 10^{-3}$ & $3.77 \times 10^{-3}$ & $2.60 \times 10^{-2}$ & $1.05 \times 10^{-2}$ \\
\hline & \multirow[t]{2}{*}{ Money market } & $-1.15 \times 10^{-1}$ & $2.17 \times 10^{-2}$ & $2.20 \times 10^{-2}$ & $3.54 \times 10^{-1}$ & $9.90 \times 10^{-2}$ \\
\hline & & $-7.88 \times 10^{-2}$ & $-6.19 \times 10^{-3}$ & $-9.02 \times 10^{-3}$ & $3.24 \times 10^{-2}$ & $2.55 \times 10^{-2}$ \\
\hline
\end{tabular}

0.608. The comparable estimates for 1998 are 0.650 and -0.008 , for a total of 0.642 . As shown in the tables, all of these component estimates for $3 \mathrm{M}$ were statistically significant in the first stage regression.

\section{THE ECONOMETRIC MODEL: SECOND-STAGE REGRESSIONS}

We attempt to identify the link between the Asian crisis and changes in firms' exposures to U.S. stock-market risk - their CAPM betas-in a secondstage regression. To this end, we gathered firmspecific data on sales to the Asian region as a proportion of total sales, on (the book values of) long-term debt and total assets, and on industry participation. In the first-stage regression approach discussed above, we used two different excessreturn measures as proxies for the Asian crisis, one based on the FT/S\&P stock-market index and the other derived from the J.P. Morgan money-market index. We run the second-stage regression using the results of each set of first-stage regressions as dependent variables.

\section{Outline of Second-Stage Estimation Procedure}

This section details the second step in our estimation procedure, which examines the channel by which the Asian crisis affected the sample firms' stock-market betas. We do this by regressing the coefficients $\hat{\delta}_{\mathrm{i}, 1997}$ and $\hat{\delta}_{\mathrm{i}, 1998}$ obtained from the asset-pricing model on a set of firm characteristics. These firm attributes are sales to the Asian region, weighted by the firm's leverage, and the firm's primary industry affiliation.

Sales exposure to Asia and the sensitivity of CAPM betas to the Asian crisis. The estimated crisis-sensitive coefficients from equation $2, \hat{\delta}_{\mathrm{i}, 1997}$ and $\delta_{i, 1998}$, serve as the dependent variables in the second-stage regression. We have one estimate for each of the 39 firms in each year, for a total of 78 observations. A standard pooled-time-series cross-section approach can be applied because the stochastic nature of the dependent variable is controlled for by the error term of the regression equation.

The explanatory variable of interest in this regression is SALES $\times$ DEBT, the product of the firm's ratio of sales to Asia (SALES) and its ratio of book value of long-term debt to total assets (DEBT). The reason for weighting SALES with DEBT is that an equity holder's actual returns are influenced by the firm's capital structure, that is, the relative amounts of debt and equity the firm has. The key point is that leverage (i.e., debt) amplifies the risk of the firm's underlying cash flows as perceived by the equity holders. See the insert on the next page for more details.

To avoid simultaneity problems in the regression model, the observations for SALES and DEBT were lagged by one calendar year. There also are indicator variables in the regression corresponding to the two-digit SIC codes of the sample firms' main lines of business. No intercept is included and one of the 19 industry indicator variables is excluded (SIC 73). This is appropriate because we do not assume a common shift in the stock-market 


\section{LEVERAGE EFFECTS ON BETA}

To illustrate the effect of leverage on an equityholder's returns more formally, let the exposure of a firm's underlying cash flows to variations in the cash flows of all firms in the market be denoted the firm's "assets beta," or $\beta_{\text {assets, }}$ and let the firm's stock-market risk exposure, or "equity beta," be written as $\beta_{\text {equity }}$. Finally, let the market comovement of returns on the firm's debt be denoted its "debt beta," or $\beta_{\text {debt }}$. Then, if $D$ is the book value of the firm's debt and $E$ is the book value of equity, it is possible to express the firm's equity beta as follows (see Brealey and Myers, 1996, pp. 213-17):

$$
\beta_{\text {equity }}=\frac{\mathrm{D}+\mathrm{E}}{\mathrm{E}} \beta_{\text {assets }}-\frac{\mathrm{D}}{\mathrm{E}} \beta_{\text {debt }}
$$

If the firm had no debt, its asset beta and its equity beta would be identical. Given positive amounts of debt in its capital structure, however, a firm's equity beta is larger than its asset beta. betas due to the Asian crisis for the reason discussed above ${ }^{18}$

The second-stage regression equation reads:

$$
\begin{aligned}
\hat{\delta}_{i, j}= & \theta \times \operatorname{SALES}_{\mathrm{i}, \mathrm{j}-1} \times \mathrm{DEBT}_{\mathrm{i}, \mathrm{j}-1} \\
& +\sum_{\mathrm{k}=1}^{\mathrm{K}} \phi_{\mathrm{k}} \mathrm{l}_{\mathrm{i}, \mathrm{k}}+\omega_{\mathrm{i}, \mathrm{t}}
\end{aligned}
$$

with $\mathrm{j}=1997$ for $\mathrm{t}=1, \ldots, 52$ and $\mathrm{j}=1998$ for $\mathrm{t}=$ $53, \ldots, 104$. The regressor $I_{i, k}$ is an industry indicator variable that takes on unit value if the corresponding firm belongs to industry $\mathrm{k}(\mathrm{k}=1, \ldots, \mathrm{K} ; \mathrm{K}=18)$, and is equal to zero otherwise.

The SALES variable is measured with error because firms reported regional sales on a nonstandardized basis during our sample period. ${ }^{19}$ Thus, we used an instrumental-variables (IV) approach, which entails ranks of the leverageweighted sales numbers as instruments for the actual leverage-weighted sales numbers. ${ }^{20}$ We tested for the presence of serial correlation using the Ljung-Box (1978) test statistic with unit lag length. ${ }^{21}$ The t-values and the Wald test statistics are based on White (1980) corrected standard errors. ${ }^{22}$ We also provide bootstrapped Student's t intervals and bootstrap-t intervals. While the first type of bootstrap intervals makes use of the Central Limit Theorem, the latter is distribution-free ${ }^{23}$

\section{Results of Second-Stage Regressions}

Second-stage regression results are presented in Tables 6 and 7. Our most important finding is that firms' leverage-weighted sales exposure to Asia is significantly related to changes in their CAPM betas.

Sales exposure to Asia and the sensitivity of CAPM betas to the Asian crisis. Tables 6 and 7 provide the results from our second-stage regression. We regress the crisis-sensitive coefficients $\hat{\delta}_{\mathrm{i}, 1997}$ and $\hat{\delta}_{i, 1998},(i=1, \ldots, 39)$ on firm characteristics. The first two columns of Table 6 show results using the Asian stock-market index as the crisis proxy, while the results in the last two columns were generated using the money-market index. The table indicates that the impact of the Asian crisis on the crisis-sensitive component of the firm's CAPM beta was associated significantly with leverage-weighted sales exposure to the region. To interpret the negative coefficients, recall that the average excess returns on the stock-market index during both 1997 and 1998, as well as the average moneymarket excess return during 1997, were negative. The negative coefficients on the variableSALES $\times$ DEBT, when multiplied by the average excess return on the crisis proxy, indicate that a worsening of the crisis increased the crisis-sensitive component of a firm's beta, the greater the firm's leverage-weighted

\footnotetext{
${ }^{18}$ We tested for the statistical significance of the intercept and found it insignificant for both crisis variables. The t-values were equal to -1.243 (stock-market index) and -1.309 (money-market index).

${ }^{19}$ For details on the collection of the sales data, see Appendix A.

${ }^{20}$ On the use of ranks as instrumental variables in regressions, see Greene (1997, pp. 440-42).

${ }^{21}$ We use the Ljung-Box test because it is related to the heteroskedasticity and autocorrelation consistent covariance matrix proposed by Newey-West (1987). This correction would be particularly important if serial correlation were a problem, although we did not find any evidence of serial correlation for either Asian excess-return series.

${ }^{22} \mathrm{~A}$ White (1980) test is not well-defined for our regression because the number of regressors in the matrix needed for the test exceeds the number of observations. This also is true after eliminating linearly dependent regressors.

${ }^{23}$ For details on these two bootstrapping procedures, see Efron and Tibshirani (1993, pp. 158-62).
} 
Table 6

\begin{tabular}{|c|c|c|c|c|}
\hline \multirow[b]{2}{*}{ Independent Variable } & \multicolumn{2}{|c|}{ Asian Stock-Market Index } & \multicolumn{2}{|c|}{ Asian Money-Market Index } \\
\hline & Coefficient & t-Statistic & Coefficient & t-Statistic \\
\hline SALES $\times$ DEBT & $-1.813 \times 10^{2}$ & $-2.620 * * *$ & $-2.563 \times 10^{2}$ & $-2.729 * * *$ \\
\hline SIC 10 & $1.153 \times 10$ & $3.268 * * *$ & -3.442 & -0.351 \\
\hline SIC 13 & 4.170 & $2.165 * *$ & $-1.127 \times 10$ & -1.406 \\
\hline $\mathrm{SIC} 16$ & $-5.752 \times 10^{-1}$ & -0.239 & -4.323 & -0.969 \\
\hline SIC 20 & 4.903 & $1.689 *$ & 5.941 & 1.590 \\
\hline SIC 26 & -5.986 & -1.499 & -6.951 & -1.486 \\
\hline $\mathrm{SIC} 28$ & $2.996 \times 10^{-1}$ & 0.169 & $-4.842 \times 10^{-1}$ & -0.142 \\
\hline SIC 29 & $-2.940 \times 10^{-1}$ & -0.055 & 7.087 & $2.076^{* *}$ \\
\hline SIC 32 & 2.172 & 0.448 & 7.452 & 1.527 \\
\hline SIC 33 & $-8.886 \times 10^{-1}$ & -0.625 & -2.249 & -1.191 \\
\hline SIC 35 & -2.534 & -1.203 & -4.263 & -0.987 \\
\hline SIC 36 & 1.008 & 0.477 & $-2.855 \times 10^{-1}$ & -0.081 \\
\hline SIC 37 & $5.544 \times 10^{-1}$ & 0.288 & 8.932 & 1.913* \\
\hline SIC 38 & $7.761 \times 10^{-1}$ & 0.190 & -3.833 & -0.750 \\
\hline SIC 45 & 3.247 & $2.128 * *$ & $-1.549 \times 10$ & -1.190 \\
\hline SIC 58 & 7.534 & $3.076^{* * *}$ & $1.401 \times 10$ & $2.767^{* * *}$ \\
\hline SIC 60 & $-5.784 \times 10^{-1}$ & -0.136 & -1.728 & -0.254 \\
\hline SIC 61 & -3.488 & -0.693 & $1.102 \times 10$ & $2.980 * * *$ \\
\hline SIC 62 & -3.452 & -1.403 & -4.371 & $-2.095 * *$ \\
\hline$R^{2}$ & \multicolumn{2}{|c|}{0.147} & \multicolumn{2}{|c|}{0.179} \\
\hline Wald statistic (SIC codes) & \multicolumn{2}{|c|}{$325.8^{* * *}$} & \multicolumn{2}{|c|}{$85.96 * * *$} \\
\hline Number of observations & \multicolumn{2}{|c|}{78} & \multicolumn{2}{|c|}{78} \\
\hline
\end{tabular}

$* / * * / * * *$ significant at 10/5/1 percent levels (t-tests are two-tailed).

sales exposure to Asia. Similarly, we would expect a greater decline in the crisis-sensitive component of a firm's beta, the greater its leverage-weighted sales exposure, if the change in the crisis proxy were positive $^{24}$ We control for industry effects in both regressions by including SIC code indicator variables representing each firm's primary industry classification.

Significance tests that are more reliable than the t-values displayed in Table 6 are shown in Table 7. For the regressor of interest, SALES $\times$ DEBT, we provide results from two alternative bootstrapping procedures that confirm our previous findings. $A$ firm's leverage-weighted sales exposure significantly affected the impact of the Asian financial crisis on the firm's CAPM beta.

It is interesting to note that the two SIC codes identified by Pollard and Coughlin (1999, p. 39) as suffering the largest declines in real exports to East
Asia during 1998-metallic ores and concentrates (SIC 10) and crude oil and natural gas (SIC 13)were identified in our regression (using the stockmarket index) as experiencing large and significant increases in the crisis-sensitive component of their market betas. For both crisis indexes, significant Wald statistics indicate that there were important industry effects even after controlling for the effect of leverage-weighted sales exposure to Asia on betas. We do not wish to emphasize these industry results, however, because the one-stage approach described in the next section does not find significant industry effects.

\footnotetext{
${ }^{24}$ The partial derivative of the expression $\left(1+\lambda_{i, j} \times \mathrm{CRISIS}_{\mathrm{t}}\right)$ from equation 1 with respect to $\delta_{i, j}$ is CRISIS $/ \beta_{i, j}$, where $\beta_{i, j}$ is the autonomous (i.e., crisis-insensitive) part of firm i's CAPM beta in year j. As Table 3 shows, all $\beta_{i, j}(i=1, \ldots, 39 ; j=1997,1998)$ were positive.
} 


\section{Table 7}

\section{Effects on Crisis-Sensitive Coefficients, $\delta_{\mathrm{i}, \mathrm{j}}$ (Bootstrapped Standard Errors)}

\begin{tabular}{cccc}
$\begin{array}{c}\text { Asian-Crisis } \\
\text { Index }\end{array}$ & $\begin{array}{c}\text { Regression } \\
\text { Coefficient }\end{array}$ & $\begin{array}{c}\text { Bootstrapped Student's t } \\
\text { Interval }\end{array}$ & $\begin{array}{c}\text { Bootstrap-t } \\
\text { Interval }\end{array}$ \\
\hline Stock market & $-1.813 \times 10^{2}$ & $+/-1.654 \times 10^{2}$ & $-1.382 \times 10^{2} ; 1.399 \times 10^{2}$ \\
Money market & $-2.563 \times 10^{2}$ & $+/-2.133 \times 10^{2}$ & $-1.790 \times 10^{2} ; 1.818 \times 10^{2}$
\end{tabular}

95-percent confidence intervals, based on 2,500 draws.

\section{A ONE-STAGE REGRESSION APPROACH}

The two-stage regression procedure applied in this article can be aggregated into a one-stage procedure. Inserting equation 3 into equation 2 results in:

$$
\text { (4) } \begin{aligned}
\mathrm{R}_{\mathrm{i}, \mathrm{t}}-\mathrm{R}_{\mathrm{f}, \mathrm{t}} & =\beta_{\mathrm{i}, \mathrm{j}}\left(\mathrm{R}_{\mathrm{m}, \mathrm{t}}-\mathrm{R}_{\mathrm{f}, \mathrm{t}}\right) \\
& +\tilde{\theta} \times \operatorname{SALES}_{\mathrm{i}, \mathrm{j}-1} \times \mathrm{DEBT}_{\mathrm{i}, \mathrm{j}-\mathrm{t}} \\
& \times \mathrm{CRISIS}_{\mathrm{t}} \times\left(\mathrm{R}_{\mathrm{m}, \mathrm{t}}-\mathrm{R}_{\mathrm{f}, \mathrm{t}}\right) \\
& +\sum_{\mathrm{k}=1}^{\mathrm{K}}\left(\phi_{\mathrm{k}} \mathrm{l}_{\mathrm{i}, \mathrm{k}}\right) \times \mathrm{CRISIS}_{\mathrm{t}} \times\left(\mathrm{R}_{\mathrm{m}, \mathrm{t}}-\mathrm{R}_{\mathrm{f}, \mathrm{t}}\right) \\
& +\tilde{\varepsilon}_{\mathrm{i}, \mathrm{t}}
\end{aligned}
$$

with $\mathrm{j}=1997$ for $\mathrm{t}=1, \ldots, 52$ and $\mathrm{j}=1998$ for $t=53, \ldots, 104$. We must drop one firm from the sample (Champion International) because it has zero values for the variable SALES (see Table 1, Panel B).

We estimated model 4 with a SUR approach that is similar to the estimation procedure we applied to model 2 . In contrast to model 2 however, the regressors in model 4 are not identical across equations, which means that the efficiency of the regression can be improved by accounting for contemporaneous correlation across the equations in a SUR model. ${ }^{25}$ Thus, we relaxed the previously imposed restriction of no contemporaneous correlation, that is, $\operatorname{Cov}\left[\varepsilon_{i, t}, \varepsilon_{j, t}\right]=0, i \neq j(i, j=1, \ldots, N)$, in favor of $\operatorname{Cov}\left[\varepsilon_{i, t}, \varepsilon_{j, t}\right]=\sigma_{1, j},(i, j=1, \ldots, N)$. We then applied an iteration procedure in the estimation of the cross-equation covariance matrix.

The important results from this one-stage regression approach were similar to those of our preferred two-stage approach (not reported). Both approaches indicate that the leverage-ad- justed sales exposure of our sample firms was significantly associated with changes in the firms' exposure to stock-market risk. Industry effects were not robust across the two approaches, however.

\section{CONCLUSION}

The Asian crisis affected consumers, investors, firms, and national economies around the world in many ways. Our analysis highlights one specific channel of influence on a sample of large U.S.-based firms. We find that the Asian crisis changed many of these firms' sensitivity to U.S. stock-market movements, that is, their CAPM betas. We find evidence that the link connecting the Asian crisis and changes in the stock-market risk exposure of our sample firms is the firms' leverage-weighted sales exposures to the crisis region.

As a firm's beta rises in response to a financial crisis, investors demand higher excess returns. This raises the firm's cost of equity capital. A firm could respond to this by reducing the share of its total sales that go to the crisis region or by decreasing its leverage. As a mitigating effect, some shrinkage in the ratio of Asian to total sales occurs automatically in the wake of such a crisis because the falling dollar value of sales constitutes a smaller fraction of total revenues. Some firms also may find it desirable to take actions to accelerate their shift away from the region or to reduce leverage.

Another mitigating effect in the stock market is the decrease in the weights of firms with increasing market betas. Even if the firm's expected earnings do not decrease, the firm's stock price must drop initially to generate the higher future returns investors demand due to the increase in the firm's

\footnotetext{
${ }^{25}$ See Greene (1997, pp. 674-76).
} 
beta. A reduction in the share price reduces the firm's market capitalization, and therefore, its weight in the market index. This effect may be reinforced by a depression of the firm's expected earnings due to a decline in sales revenues from the crisis region.

\section{REFERENCES}

Black, Fischer, and Myron S. Scholes. "The Pricing of Options and Corporate Liabilities," Journal of Political Economy (May-June 1973), pp. 637-54.

Brealey, Richard A., and Stewart C. Myers. Principles of Corporate Finance, $5^{\text {th }}$ ed., McGraw-Hill, 1996.

Campbell, John Y., and John H. Cochrane. "Explaining the Poor Performance of Consumption-Based Asset-Pricing Models," NBER Working Paper 7237, July 1999.

Economic Report of the President (Washington, D.C.: United States Government Printing Office, 1999).

Efron, Bradley, and Robert J. Tibshirani. An Introduction to the Bootstrap, Chapman \& Hall, 1993.

Fama, Eugene F., and Kenneth R. French. "The CrossSection of Expected Stock Returns," Journal of Finance (June 1992), pp. 427-65.

Greene, William H. Econometric Analysis, $3^{\text {rd }}$ ed., Prentice-Hall, 1997.

Jagannathan, Ravi, and Zhenyu Wang. "The Conditional CAPM and the Cross-Section of Expected Returns," Journal of Finance (March 1996), pp. 3-53.
Ljung, Greta M., and George E.P. Box. "On a Measure of Lack of Fit in Time Series Models," Biometrica (June 1978), pp. 297-303.

Merton, Robert C. "An Intertemporal Capital Asset Pricing Model," Econometrica (September 1973), pp. 867-87.

Newey, Whitney K., and Kenneth D. West. "A Simple, Positive Semi-Definite, Heteroskedasticity and Autocorrelation Consistent Covariance Matrix," Econometrica (May 1987), pp. 703-08.

Pollard, Patricia S., and Cletus C. Coughlin. “Going Down: The Asian Crisis and U.S. Exports," this Review (March/April 1999), pp. 33-45.

Ross, Stephen A. "The Arbitrage Theory of Capital Asset Pricing," Journal of Economic Theory (December 1976), pp. 341-60.

Schmid, Frank A. "Quality Spreads in the Bond Market," Monetary Trends (July 1999), < www.stls.frb.org/docs/ publications/mt/1999/cover7.pdf> .

White, Hal bert. "A Heteroskedasticity-Consistent Covariance Matrix Estimator and a Direct Test for Heteroskedasticity," Econometrica (May 1980), pp. 817-38. 
We analyze 39 of the 100 firms in the "Standard $\&$ Poor's 100" stock-market index for calendar years 1997 and 1998. We were limited to this subset of the S\&P 100 because the other firms did not provide a sufficiently detailed breakdown of international sales. Our criterion for inclusion in the sample was that the firm's reports must allow us to calculate the ratio of sales to customers in Asia to worldwide sales (where both items are stated in U.S. dollar terms).

Sales data and balance-sheet information (long-term debt and total assets) were taken from each firm's annual reports. Data on consolidated sales (including all subsidiaries) for each firm were obtained from the income statement. Data on sales to customers in Asia were taken from the notes to the consolidated financial statements. For firms whose fiscal years did not coincide with the calendar year, the dollar amounts of sales and the end-of-fiscal year items were interpolated linearly to determine corresponding calendar-year values.

\section{Construction of the SALES variable and lines of business}

Data on international sales are provided in the notes to the consolidated financial statements in annual reports of U.S. corporations. Unfortunately, current reporting of international sales is not standardized. Many companies provide al most no detail beyond a breakdown into domestic and foreign sales. Only 39 of the S\&P 100 firms provided enough country or area detail to allow us to calculate sales to the Asia/Pacific region. For example, nine companies included sales data for areas outside Asia as part of their totals for Asia/Pacific. We assumed that these firms combined sales totals from regions where they do relatively little business with regions where they are more active. We believe the non-Asian sales included in the Asia/Pacific totals are insubstantial.

A second problem is that firms that distinguish between sales to other departments or divisions within the organization (intracompany sales) and sales to unaffiliated customers (third-party sales) do not always do so on a consistent basis when presenting geographic breakdowns. In four cases, firms did not distinguish between intracompany and third-party sales on a geographic basis. For these four firms we know the total amount of intracompany sales on a consolidated (world wide) basis, but we do not know what percentage of sales to Asia were intracompany. In these four instances, the sum of sales totals to the various world regions will be greater than total sales (because intracompany sales have not been eliminated). Fortunately, intracompany sales averaged only 5.4 percent of third-party sales for these four firms.

The SIC two-digit code for each firm's main line of business was taken from the $10-K$ filings found on the Securities and Exchange Commission's EDGAR website < http://www.sec.gov/edgarhp.htm> ; 1998.

\section{Financial Markets Data}

Weekly total-return data for our 39 sample companies and the S\&P 500 index for 1997 and 1998 were purchased from Standard \& Poor's Compustat and DRI respectively. Weekly returns were cal culated from Friday to Friday (closing prices), with adjustment for stock splits and dividends.

The risk-free rate was proxied by a strategy of investing in three-month Treasury bills each week, holding the bill one week, then rolling over into the new three-month T-bill. We collected the "on-the-run" three-month yield as well as the "off-the-run" yield of the bill issued the previous week for each week during 1997 and 1998 from the Wall Street Journal. Using these yields, we calculated prices. Three-month T-bill log returns were calculated as follows:

$$
\log \left(\frac{P_{\text {off }, t}}{P_{\text {on }, t-1}} r_{t-1}\right)
$$

where $P_{\text {off,t }}$ is the price of the "off-the-run" issue at time t; Pon,t-1 is the price of the "on-the run" issue at time $t-1 ; r_{t-1}$ is the value of the return index at time $t-1$ ( $t-1>0$ ); and $r_{0}$ equals 100 .

We used the log returns on two indexes of Asian securities to measure the economic situation in Asia. These were the FT/S\&P Actuaries World Indices-Pacific Excluding Japan, a Pacific-region stock-markets index, and the J.P. Morgan Emerging Local Markets Index Plus (ELMI+)-Asia, a Pacificregion emerging-markets money-market index. The FT/S\&P World Indices are owned by FTSE, 
International Limited, Goldman, Sachs \& Co., and Standard \& Poor's. These indices are compiled by FTSE International and Standard \& Poor's in conjunction with the Faculty of Actuaries and the Institute of Actuaries. More information on the J.P. Morgan Emerging Local Markets Index Plus can be found in J.P. Morgan's Emerging Markets Bond Index Monitor. Both indexes are stated in U.S. dollar terms based on current exchange rates. Further details are provided below.

At year-end 1998, the FT/S\&P Actuaries World Indices-Pacific Excluding Japan index included Australia (75 companies), Hong Kong (66), Indonesia (26), New Zealand (18), The Philippines (22), Singapore (41), and Thailand (35). Malaysia (106 companies as of September 25, 1998) was removed from the index on October 1, 1998, following the Malaysian government's introduction of investment exchange controls on September 1, 1998.

According to the ground rules for the construction and maintenance of the FT/S\&P Actuaries World Indices, criteria for inclusion in the World Indices are the following:

- Direct equity investment by non-nationals must be permitted;

- Accurate and timely data must be available;

- No significant exchange controls should exist that would prevent the timely repatriation of capital or dividends;

- Significant international investor interest in the local equity market must have been demonstrated;

- Adequate liquidity must exist.

Companies whose business is that of holding equity stakes in other firms or other investments are not excluded necessarily. Equity-holding firms that are excluded include split-capital investment trusts and companies whose share price is a direct derivation of the values of underlying holdings, such as mutual funds. Only shares listed on a stock exchange are eligible for inclusion. Wherea company does not list all its shares in an eligible class, or does not list an entire class, these partially listed or unlisted shares are not eligible. All securities comprising the bottom 5 percent of a country's market capitalization are excluded from the indices.
A security is totally excluded if foreign investors are barred from ownership. Calculation of the U.S. dollar version of this index is explained in detail in the FT/S\&P Actuaries World Indices Ground Rules at $<$ http://www.ftsecom> .

The second financial-market index we used was the J.P. Morgan Emerging Local Markets Index Plus $(E L M I+)($ U.S. Dollar Index)-Asia. The ELMI+ tracks total returns for local-currency-denominated moneymarket instruments in 24 emerging markets. It is predominantly non-Latin America weighted and includes four regional composites, Asia (48 percent target weight as of January 29, 1999), Europe (18.26), Latin America (23.07), and Middle East/Africa (10.67). The ELMI + employs a liquidity-sensitive weighting system, which uses exports plus imports as a base. Its portfolio consists of FX forwards, wherever possible, to represent a country's money markets.

A country is selected if it has been identified as an emerging market with an economy large enough to support significant capital flows, and has accessible liquid local-currency-denominated money-market instruments, either on- or offshore.

The Asian regional sub-index was used for this analysis. The countries included in the Asian regional composite are China (4.167 percent of the total index), Hong Kong (20.833), India (4.167), Indonesia (16.67), The Philippines (4.167), Singapore (20.833), South Korea (4.167), Taiwan (4.167), and Thailand (20.833). A special August month-end rebalancing was performed to account for Russia's removal from the index, and a special September 8, 1998, rebalancing was performed to account for Malaysia's removal.

Target weights are derived by applying a series of caps to the three-year, rolling, trade-weighted allocation for each country. Specifically, for countries with convertible currencies, the weight per country is limited to no more than 10 percent of the total index. For countries with nonconvertible currencies or impediments to investing onshore, the weight per country is limited to no more than 2 percent of the index. For each country subindex, a ladder of three instruments was constructed, by initially investing in one, two-, and three-month instruments. Each month, the proceeds of the maturing instrument is reinvested in a new three-month instrument. 
Appendix B: DEFINITION OF VARIABLES

\section{Dependent Variables}

The dependent variable in the asset-pricing regressions is each sample firm's weekly excess return, defined as the difference between the log total return on the firm's stock and the risk-free return. A second-stage regression uses parameter estimates from the first-stage regression as the dependent variable. This parameter is the crisis-sensitive component of each firm's estimated market beta, $\hat{\delta}_{i, j}(i=1, \ldots, 39 ; j=1997,1998)$.

\section{Independent Variables}

We used four total-return indexes with each return denoted as follows:
$\mathrm{R}_{\mathrm{i}}$ : $\quad$ Log change in total-return index of firm $\mathrm{i}$ (weekly);
$R_{m}: \quad$ Log change in S\&P 500 total-return index (weekly);
$\mathrm{R}_{\mathrm{f}}: \quad$ Log change in three-month T-bill total- return index (weekly);

$\mathrm{R}_{\text {Asia: }}$ Alternatively defined as log change in the FT/S\&P total-return index or in the J.P.M. total-return index (weekly).

Firm-specific variables include the following:

SALES $: \quad$ Ratio of dollar amount of sales to customers in Asia to dollar amount of consolidated sales of firm i (annual);

DEBT $_{j}$ : $\quad$ Ratio of book value of long-term debt of firm i to its total assets (end of calendar year; annual);

SICX $x_{i}: \quad$ Indicator variable: 1 if the firm's main line of business falls into the two-digit SIC division $x, 0$ otherwise (annual). 
REVIEW 